\title{
In vitro anticancer activity of methanolic extract of Granulocystopsis sp., a microalgae from an oligotrophic oasis in the Chihuahuan desert
}

\author{
Faviola Tavares-Carreón ${ }^{1}$, Susana De la Torre-Zavala ${ }^{1}$, Héctor F Arocha-Garza ${ }^{1}$, Valeria Souza ${ }^{2}$, Luis J Galán- \\ Wong ${ }^{1}$, Hamlet Avilés-Arnaut ${ }^{\text {Corresp. } 1}$ \\ 1 Facultad de Ciencias Biológicas, Instituto de Biotecnología, Universidad Autónoma de Nuevo León, San Nicolás de los Garza, Nuevo León, México
2 Departamento de Ecología Evolutiva, Instituto de Ecología, Universidad Nacional Autónoma de México, Coyoacán, Mexico \\ Corresponding Author: Hamlet Avilés-Arnaut \\ Email address: hamlet.avilesarn@uanl.edu.mx
}

With the purpose of discovering new anticancer molecules that might have fewer side effects or reduce resistance to current antitumor drugs, a bioprospecting study of the microalgae of the Cuatro Cienegas Basin (CCB), an oasis in the Chihuahuan desert in Mexico was conducted. A microalgae was identified as Granulocystopsis sp. through sequencing the $r b c L$ gene and reconstruction of a phylogenetic tree, and its anticancer activities were assessed using various in vitro assays and different cell lines of human cancers, including lung, skin melanoma, colorectal, breast, and prostatic cancers, as well as a normal cell line. The values of $\mathrm{IC}_{50}$ of the microalgae methanolic extract using the MTT assay were lower than $20 \mu \mathrm{g} / \mathrm{ml}$, except that in the lung cancer line and the normal cell line. In vitro, the microalgae extract caused the loss of membrane integrity, monitored by the trypan blue exclusion test and exhibited marked inhibition of adhesion and cell proliferation in cancer cell lines, through the evaluation of the clonogenic assay. Also, typical nuclear changes of apoptotic processes were observed under the microscope, using the dual acridine orange/ethidium bromide (AO/EB) fluorescent staining. Finally, the microalgae extract increased the activity of caspases 3 and 7 in skin melanoma, colon, breast and prostate cancer cells, in the same way as the apoptotic inductor and powerful antitumoral drug, doxorubicin. This study shows the anticancer activity from Granulocystopsis sp., a microalgae isolated from the CCB. 
1 In vitro anticancer activity of methanolic extract of

2 Granulocystopsis sp., a microalgae from an

3 oligotrophic oasis in the Chihuahuan desert.

4

5

6 Faviola Tavares-Carreón ${ }^{1}$, Susana De la Torre-Zavala ${ }^{1}$, Héctor F. Arocha-Garza ${ }^{1}$, Valeria

7 Souza $^{2}$, Luis J. Galán-Wong1, Hamlet Avilés-Arnaut ${ }^{1 *}$

8

$9 \quad{ }^{1}$ Facultad de Ciencias Biológicas, Instituto de Biotecnología, Universidad Autónoma de Nuevo

León, Avenida Universidad S/N, Ciudad Universitaria, CP 66455, San Nicolás de los Garza, NL,

México.

${ }^{2}$ Departamento de Ecología Evolutiva, Instituto de Ecología, Universidad Nacional Autónoma de

México, México City, México

*Corresponding Author:

Hamlet Avilés-Arnaut ${ }^{1}$

Av. Universidad s/n, Ciudad Universitaria, San Nicolás de los Garza, Nuevo León, C.P. 66450.

México.

Email address: hamlet.avilesarn@,uanl.edu.mx 


\section{Abstract}

25 With the purpose of discovering new anticancer molecules that might have fewer side effects or reduce resistance to current antitumor drugs, a bioprospecting study of the microalgae of the Cuatro Cienegas Basin (CCB), an oasis in the Chihuahuan desert in Mexico was conducted. A microalgae was identified as Granulocystopsis sp. through sequencing the $r b c L$ gene and reconstruction of a phylogenetic tree, and its anticancer activities were assessed using various in vitro assays and different cell lines of human cancers, including lung, skin melanoma, colorectal, breast, and prostatic cancers, as well as a normal cell line. The values of $\mathrm{IC}_{50}$ of the microalgae methanolic extract using the MTT assay were lower than $20 \mu \mathrm{g} / \mathrm{ml}$, except that in the lung cancer line and the normal cell line. In vitro, the microalgae extract caused the loss of membrane integrity, monitored by the trypan blue exclusion test and exhibited marked inhibition of adhesion and cell proliferation in cancer cell lines, through the evaluation of the clonogenic assay. Also, typical nuclear changes of apoptotic processes were observed under the microscope, using the dual acridine orange/ethidium bromide (AO/EB) fluorescent staining. Finally, the microalgae extract increased the activity of caspases 3 and 7 in skin melanoma, colon, breast and prostate cancer cells, in the same way as the apoptotic inductor and powerful antitumoral drug, doxorubicin. This study shows the anticancer activity from Granulocystopsis sp., a microalgae isolated from the CCB.

\section{Introduction}

44 Cancer is one of the most important causes of death worldwide and is continuously stimulating the search for new bioactive molecules from natural sources. There is an urgent need of new anticancer drugs because tumor cells are developing resistance against currently available drugs, 
47 like vinca alkaloids and taxanes (Singh et al. 2011) and some anticancer drugs have side effects

48 that can threaten life because they do not discriminate normal and tumoral cells.

49 During the last decade, microalgae have been extensively used as nutritional or pharmaceutical

50 component to humans and animals. They are considered a potentially new and valuable source of

51 biologically active compounds because can be easily cultured, have short generation times and

52 several anticancer compounds from algae are in clinical or preclinical trials (Varshney \& Singh

53 2013).

54 Microalgae are unicellular, simple, photosynthetic organisms that have colonized every type of

55 ecological niche. Their adaptive diversification to a multitude of habitats and extreme conditions

56 make them good candidates for drug discovery because they have developed defense compounds

57 to resist changes in solar radiation, temperature, $\mathrm{pH}$, salinity, etc (Irigoien et al. 2004). One of the

58 most extreme habitats in the north of México is the Cuatro Cienegas Basin (CCB), located in the

59 Chihuahuan desert.

60 CCB has several hydrological systems which have been listed as a Wetland of International

61 Importance within the international Ramsar Convention (Souza et al. 2012). This area is famous

62 for its remarkable biodiversity (Minckley \& Cole 1968; Souza et al. 2006) despite its extremely

63 unbalanced nutrient stoichiometry between nitrogen $(\mathrm{N})$ and phosphorus (P) (Elser et al. 2005;

64 Lopez-Lozano et al. 2012; Souza et al. 2008). These specific conditions created a unique niche

65 that has persisted generating endemic lineages of microbes (Souza et al. 2008; Souza et al. 2018).

66 Nevertheless, this very well characterized environment is now dry and most of its macrobiota,

67 extinct. Before the collapse of the aquifer, the biotechnological potential of microalgae from

68 Churince was evaluated in the search for new alternatives against cancer. Therefore, the aim of

69 the present study was to explore the anticancer potential of the methanolic extract of 
Granulocystopsis sp, a microalgae isolated from the Churince intermediate Lagoon in CCB. The antitumor activity was evaluated in breast, colorectal, prostate and skin melanoma, through the evaluation of its cytotoxic activity, morphological analysis, cell adhesive properties and apoptosis induction. This study highlights the importance of conservation of this unique oasis, given its enormous biotechnological potential.

\section{Material and Methods}

\section{Sampling and isolation of microalgae strain Chu2}

Microalgae specimen was hand collected at the intermediate Lagoon in the Churince hydrological system $\left(2^{\circ} 50.830^{\prime} \mathrm{N} 10^{\circ} 09.335^{\prime} \mathrm{W}\right)$, located in CCB, Coahuila, México during period between February and July 2016 under SEMARNAT scientific permit No.

SGPA/DGVS/03121/15. For isolation of microorganisms, the sample (fresh water) was homogenized in sterile water and aliquots were placed on Petri dishes containing agar based media: BG-11 (17.6 mM NaNO $3,0.23 \mathrm{mM} \mathrm{K}_{2} \mathrm{HPO}_{4}, 0.3 \mathrm{mM} \mathrm{MgSO}{ }_{4} \cdot 7 \mathrm{H}_{2} \mathrm{O}, 0.24 \mathrm{mM}$

$\mathrm{CaCl}_{2} \cdot 2 \mathrm{H}_{2} \mathrm{O}, 0.031 \mathrm{mM}$ Citric Acid $\cdot \mathrm{H}_{2} \mathrm{O}, 0.021 \mathrm{mM}$ Ferric Ammonium Citrate, $0.0027 \mathrm{mM}$ $\left.\mathrm{Na}_{2} \mathrm{EDTA} \cdot 2 \mathrm{H}_{2} \mathrm{O}, 0.19 \mathrm{mM} \mathrm{Na} \mathrm{CO}_{3}\right)$ supplemented with carbenicillin $50 \mu \mathrm{g} / \mathrm{mL}$.

Purity of strain was resolved by sequential restrikes onto new agar plates and a pure strain named Chu2 (Churince strain $\mathrm{n}^{\circ} \underline{2}$ ) was inoculated in liquid BG-11 medium for culture maintenance and up-scaled growth. Cultures were kept in a climate chamber at $20^{\circ} \mathrm{C}$ in a $16: 8 \mathrm{~h}$ light:dark cycle, $70 \%$ of relative humidity and $100 \mu \mathrm{mol}$ photons $\mathrm{m}^{-2} \mathrm{~s}^{-1}$. 


\section{Microalgae morphology}

92 The microalgae Chu2 was observed using the light microscope Olympus BX-53 equipped with

93 phase contrast and a Qimaging camera (model Micropublisher 3.3 RTV) and Q-capture pro 7

94 software. The morphological identification was performed using the keys for the members of the

95 Phylum Chlorophyta (John \& Tsarenko 2011).

96

97 Molecular identification of Chu2 microalgae.

98 Genomic DNA was extracted and used to amplify $r b c L$ (rubisco gene) (Table 1). The $r b c L$ gene 99 was chosen because it is encoded by the chloroplast genome and is considered a housekeeping 100 gene, and therefore conserved and appropiate for family and genus level phylogenetics. PCR 101 reactions were exposed to the following profile: 35 cycles of denaturation $\left(94^{\circ} \mathrm{C}\right.$ for $\left.1 \mathrm{~min}\right)$, 102 primer annealing $\left(55^{\circ} \mathrm{C}\right.$ for $\left.1 \mathrm{~min}\right)$, and extension $\left(72^{\circ} \mathrm{C}\right.$ for $\left.2 \mathrm{~min}\right)$. The PCR products were 103 ligated into $\mathrm{pCR}^{\mathrm{TM}} 4-\mathrm{TOPO}{ }^{\mathrm{N}}$ (ThermoFisher Scientific) to generate plasmids that were 104 sequenced by LANBAMA-IPICYT, Mexico (Table 2).

\section{Phylogenetic reconstruction}

107 The $r b c L$ sequences were assembled using CodonCode Aligner 5.1 software (CodonCode

108 Corporation, Dedham, MA). The resulting contigs were aligned in Bioedit to build a consensus 109 sequence. The resulting sequence was aligned in the NCBI database (http:

110 //www.ncbi.nlm.nih.gov/) using the Basic Local Alignment Search Tool (BLAST) in order to 111 identify the closest related sequences at genus-level affiliations to the Chu2 microalgae $r b c L$ 112 gene (GenBank MH370163). After BLAST analysis of the sequenced gene, a data set of $37 \mathrm{rbcL}$ genes from the well characterized and validated genus of the Oocystaceae family (Stenclova et 
114 al. 2017) was used to construct the phylogenetic tree. The tree was rooted with Chlorella

115 vulgaris (Chlorellaceae family) $r b c L$ gene. The $r b c L$ sequence from $\mathrm{Chu} 2$ and the data set were

116 aligned with Clustal V (Higgins 1994) and trimmed to $796 \mathrm{pb}$ by MEGA 7: Molecular

117 Evolutionary Genetics Analysis version 7.0 for bigger datasets (Kumar et al. 2016). The model

118 selection was performed using statistical and evolutionary analysis of multiple sequence

119 alignments TOPALi v2 (Milne et al. 2009). To construct the phylogenetic tree from the genus of

120 Oocystaceae family, the Maximum-likelihood (ML) method was used with MEGA software v. 7

121 (Kumar et al. 2016) and the Generalized time-reversible GTR+G parameter as an evolutionary

122 model. The nodes reliability was estimated using the ML bootstrap percentages obtained after

1231,000 replications (Felsenstein 1985). Bootstrap values for ML in the range from 0.7 to 1 were

124 marked with black Rhombus.

125

126 Preparation of Microalgae Extract

127 Pure cultures were inoculated in Erlenmeyer flasks with 1L of fresh media (BG-11) and

128 incubated at $25^{\circ} \mathrm{C}$, under $16 \mathrm{~h}$ day $/ 8 \mathrm{~h}$ dark cycle, in a bioclimate chamber for $2-3$ weeks. The

129 resulting media was spun down to separate the microalgae biomass from the broth. Biomass was

130 extracted with $\mathrm{MeOH}$ 1:1 (m/v) (Sigma-Aldrich) for 5 days. The crude extracts were evaporated

131 under vacuum at $50^{\circ} \mathrm{C}$ (Yamato RE801) to remove methanol residues. For the cytotoxicity

132 assays, the dried methanol extract was dissolved in dimethylsulfoxide (DMSO) to obtain a final

133 concentration of $100 \mathrm{mg} / \mathrm{mL}$ (stock) and diluted in 1x PBS.

134

135 Cell lines and cell culture 
136 Cell lines were cultured in RPMI or DMEM with FBS $(10 \% \mathrm{v} / \mathrm{v})$. The cell culture was

137 performed in an incubator at $37^{\circ} \mathrm{C}$ and $5 \% \mathrm{CO}_{2}$ to ensure growth and viability. The tumor [breast

138 (HTB-22), colorectal (HTB-38), skin melanoma (HTB-72) and prostate (HTB-81)] and Vero

139 normal cell (CCL-81); were purchased from the American Type Culture Collection (ATCC).

\section{Cytotoxicity Assay}

142 Cytotoxicity effects were determined by MTT (3-(4, 5-dimethylthiazolyl-2)-2,

143 5-diphenyltetrazolium bromide) assays, as previously described by (van Meerloo et al. 2011).

144 After incubation for $24 \mathrm{~h}$, cells were treated with various concentrations of Granulocystopsis sp. extract and incubated for $48 \mathrm{~h}$. An MTT solution $(5 \mathrm{mg} / \mathrm{mL})$ was added to each well and further incubated for $4 \mathrm{~h}$ at $37^{\circ} \mathrm{C}$. A medium supplemented with DMSO was used as a control.

Doxorubicin $(10 \mu \mathrm{g} / \mathrm{mL})$ treated cells and untreated cells were used as positive control and negative control, respectively. $\mathrm{IC}_{50}$ were calculated for each cancer cell line using the equations previously reported, plotting a linear regression curve and using the same in succeeding assays (Eskandani et al. 2014). Each concentration of the algal extract was independently assayed three times with three technical replicates.

\section{Trypan blue exclusion test of cell viability}

Different cancer cell lines were grown for $24 \mathrm{~h}$. Subsequently, the cells were exposed to the microalgae extract at the concentration corresponding to their $\mathrm{IC}_{50}$ and cell viability was evaluated at 12, 24, 36 and 48 hours. After $48 \mathrm{~h}$ of treatment, the medium was replaced with

157 fresh medium (without extract) and the cells were cultured for an additional $12 \mathrm{~h}$ and $24 \mathrm{~h}$.

158 Trypan blue test was used for the viability assay (Strober 2015). Human cancer and normal cell 
159 lines were used without treatment, as negative control. Five technical replicates were performed

160 for each of the three independent experiments.

161

162 Clonogenic assay of cell in vitro

163 Culture dishes were seeded with 100-110 cells and incubated for $24 \mathrm{~h}$ in order to perform the

164 clonogenic assay as previously described (Rafehi et al. 2011). Subsequently, the cells were

165 exposed to Granulocystopsis sp. extract for $48 \mathrm{~h}$. After treatment, a medium without microalgal

166 extract was added, and cells were cultured for two weeks. To determine the number of colonies

167 per plate, the cultures were stained and analyzed using ImageJ software (Collins 2007) and

168 progenitor frequencies expressed as the total number of colonies obtained per 100 cells seeded.

169 Three independent experiments were performed with three technical replicates each.

170

171 Cell morphology and adhesion assay in vitro

172 Cell attachment assay was carried out with some modifications (Xia et al. 2005). Briefly, $5 \times 10^{5}$

173 cells were treated with Granulocystopsis sp. extract for $48 \mathrm{~h}$ in a 6-well plate and then were

174 detached and plated back on a new culture plate. After each incubation period of 6 to $24 \mathrm{~h}$, the

175 cell attachment status and morphology were observed, and photographs were captured by camera

176 infinity 1-2, Luminera. As a control, cells were cultivated in the same plate without the

177 microalgae extract.

178

179 Dual acridine orange/ethidium bromide (AO/EB) fluorescent staining.

180 The AO/EB double staining assay was performed as previously described (Cohen 1993). Briefly,

181 melanoma and prostate cancer cells were treated with Granulocystopsis sp. extract for $48 \mathrm{~h}$, 
182 trypsinized and stained with AO/EB dye. A Nikon TS100 microscope was used to see and 183 examine the cell suspensions at $400 \times$ magnifications. Results were expressed as means \pm SE for 184 three independent determinations.

186 Caspase assay

187 Cells were seeded, treated with $\mathrm{Chu} 2$ methanol extract at their respective $\mathrm{IC}_{50}$ values, and 188 incubated for 48 h. Caspases activity was then determined using Caspase-3/7 Fluorescence 189 Assay Kit (Cayman cat. no. 10009135) (Martinotti et al. 2018) according to the manufacturer's instructions. Three independent experiments were performed with three technical replicates each.

Statistical Data Analysis.

Data from the clonogenic assay, caspase activity and AO/EB staining, were expressed as the mean \pm SEM from three experiments and GraphPad Prism 7 software was used to perform Students $t$-Test or one-way analysis of variance (ANOVA) followed by Tukey test for multiple comparisons. The significance level was set at $p<0.05$.

\section{Results}

\section{Identification of the microalgae strain Chu2}

The Chu2 microalgae isolated from in the now extinct Churince hydrological system in CCB,

202 Coahuila, México, was examined by microscopy and it was found to be a Chlorophyta. The cells are ellipsoidal with pointed apices, granular appearance, parietal chloroplast with a pyrenoid, 1012-micron size, with two cells or multiples of 2 (up to 8) within an expanded lemon-shaped 
205

206

207

208

209

210

211

212

213

214

215

216

217

218

219

220

221

222

223

224

225

226

227

mother cell wall (Fig. 1). Because these characteristics are present in some of the members of the Oocystaceae family, the Chu2 $r b c L$ gene was amplified with two pairs of primers (Table 1), cloned (Table 2), sequenced and used to construct the phylogenetic tree from the genus of Oocystaceae family in order to identify the closest related homologs in genus-level affiliations to the Chu2 microalgae. Phylogenetic analysis provided the confirmation that the isolate Chu2 belonged to a member of Granulocystopsis genus (Fig. 2), and the isolate was designated as Granulocystopsis sp. (Chlorellales: Oocystaceae).

\section{Cytotoxic activity of Granulocystopsis sp. extract on different human cancer cell lines.}

To evaluate the cytotoxic properties of Granulocystopsis sp. methanol crude extract, an MTT assay was performed on five human carcinoma cell cultures: lung, prostate, breast, colorectal and skin melanoma. The cytotoxic activity of the microalgae extracts is shown in Table 3 . The Granulocystopsis sp. extract induced strong cytotoxicity in four cancer cell lines $(<20 \mu \mathrm{g} / \mathrm{mL})$, prostate cancer cells showing striking sensitivity to treatment with the microalgae extract $\left(\mathrm{IC}_{50}\right.$, $13.74 \pm 2.06 \mu \mathrm{g} / \mathrm{mL}$; Table 3). Interestingly, the Granulocystopsis sp. extract had no cytotoxic effect on the lung cancer cell line. For that reason, the lung cancer cell line was discarded in the next stage of experiments. The U.S. National Cancer Institute (NCI) has established three groups of crude extracts from natural sources according to their degree of cytotoxicity: inactive $\left(\mathrm{IC}_{50}\right.$ $>100 \mu \mathrm{g} / \mathrm{mL}$ ), moderately active ( $\mathrm{IC}_{50} 20$ to $100 \mu \mathrm{g} / \mathrm{mL}$ ) and active $\left(\mathrm{IC}_{50}<20 \mu \mathrm{g} / \mathrm{mL}\right.$ ) (Skehan et

al. 1990). The $\mathrm{IC}_{50}$ of Granulocystopsis sp. microalgae extract on the 4 cancer lines was less than $20 \mu \mathrm{g} / \mathrm{mL}$, so the extract is "active" according to the NCI, but also is three times less active in the healthy Vero cell line, showing a slight differential effect between tumor and normal cells. 
229 Viability (time-dependent) in cells exposed to the extract of Granulocysptopsis sp.

230 The trypan blue test was performed to determine changes in the viability of each cell line after

231 being exposed to the Granulocytostopsis sp. extract with respect to the time. The assay was

232 performed during $48 \mathrm{~h}$ of treatment and $24 \mathrm{~h}$ of recovery time after treatment. Interestingly, the

233 greatest decrease in the viability in prostate cells was observed between 0 and $12 \mathrm{~h}$ of treatment,

234 between 12-24 h of treatment in those of breast cancer and between 24 and $36 \mathrm{~h}$ of treatment in

235 those of melanoma and colon. Each cell line responds differently to the extract although the

236 viability of all the cell lines decreased in a time-dependent manner during the treatment with the

237 microalgae extract. The melanoma, colorectal, and prostate cancer cells showed $70-90 \%$ of

238 viability after $24 \mathrm{~h}$ of treatment, but breast cells reached only $55 \%$ of viability over the same

239 time. After $48 \mathrm{~h}$ of treatment, the melanoma, colorectal, and prostate cancer cells showed

240 decreased viability to below 50\%, whereas the viability of Vero cells just decreased to $85 \%$ (Fig.

241 3). When 48 hours of treatment ended, the cells were incubated with fresh media and monitored

242 for $24 \mathrm{~h}$. The cancer cells recovered the viability only $10 \%$ after $24 \mathrm{~h}$ recovery. In contrast, the

243 Vero cell line had almost 100\% recovery after the treatment (Fig. 3). Again, the

244 Granulocystopsis sp. extract appears to have a cytotoxic and selective effect against prostate,

245 breast, melanoma and colon cancer cells, but with lesser effects on the viability of normal Vero 246 cells.

\section{Effect of Granulocystopsis sp. extract on the proliferation of tumor cell lines.}

249 It was investigated whether the microalgae extract could affect the proliferative activity (the 250 ability to form a colony from a single cell), using the clonogenic assay. In the four cancer cell 
251 lines treated with microalgal extract, a significant proliferation inhibition was observed (Fig. 4 D,

$252 \mathrm{~F}, \mathrm{H}, \mathrm{J})$. The tumor cells treated with the microalgae extract reduced the ability to form colonies

253 by at least $50 \%$, whilst the healthy cell line (Vero) just by $20 \%$ (Fig. $4 \mathrm{~K}$ ). According to these

254 results, the Granulocystopsis sp. extract has the potential to inhibit the formation of twice tumor

255 colonies in vitro, compared to normal cells.

256

257 Effect of Granulocystopsis sp. extract on cell adhesion and morphology of human cancer 258 cells.

259 The effect of Granulocystopsis sp. extract on cell adhesion and cell morphology was evaluated

260 by detaching the cells treated with the microalgae extract and plating them in a new plate with

261 fresh medium (extract free). Cells that do not attach to the plate are rounded. Figure 5 shows the

262 level of adhesion and cell morphology between prostate, melanoma, colorectal and breast cancer

263 cell lines with or without the microalgae extract in an interval of $24 \mathrm{~h}$. Vero cells were used as a

264 normal cell. Cells without the extract changed their morphology from round to flattened and

265 adhered to the plate 6 hours after incubation (Figs. 5J, 5R and 5HH), reaching almost 100\%

266 confluence after $24 \mathrm{~h}$ of incubation (Figs. 5B, 5L, 5T and 5BB). However, the cells treated with

267 Granulocystopsis sp. extract, kept their round shape or remained in suspension after 6 hours of

268 incubation (especially prostate and breast cells) (Figs. 5N and 5LL), delaying their adhesion to

269 the plaque 12 hours. Some treated colorectal, breast and prostate cells (Figs. 5 FF, 5 NN and 5P)

270 were still unattached $24 \mathrm{~h}$ later, hence indicating that the adhesive capability of the treated cells

271 was retarded.

272

Granulocystopsis sp. extract and apoptosis in human cancer cell lines. 
274 To determine whether the cell adhesion, cytotoxic activity and inhibition of cell proliferation by

275 the microalgae extract were due to the induction of apoptosis, the acridine orange/ethidium

276 bromide $(\mathrm{AO} / \mathrm{EB})$ staining was assessed to detect nuclear changes and apoptotic body formation.

277 The proapoptotic activity of Granulocystopsis sp. extract was investigated with respect to

278 nuclear condensation of cells by fluorescence microscopy. Fluorescence microscopy images

279 clearly showed nuclear changes such as chromatin condensation, nuclear fragmentation and

280 formation of apoptotic bodies in the skin melanoma and prostate cancer cell lines treated with

281 Granulocystopsis sp. extract by 48 h (Figs. 6C-6D). Quantification of the live cells, early and

282 late apoptosis stage and necrotic cell population in the treated (Figs. 6C-6D) and control cells

283 (Figs. 6A-6B) was measured. The skin melanoma and prostate cancer cells increased the early

284 apoptosis stages by $35 \%$ and $45 \%$ and the late apoptosis stage by $38 \%$ and $20 \%$, respectively

285 (Figs. 6G-6H). In addition, the crude extract of the microalgae induced levels of early apoptosis

286 similar to those obtained in cells treated with commercial antitumor compounds, such as

287 Doxorubicin (Figs. 6E-6H). According to results, it was concluded that the Granulocystopsis sp.

288 extract can induce in vitro apoptotic events in skin melanoma and prostate cancer cell lines.

\section{Caspase-3 and -7 activities in cancer cell lines treated with Granulocystopsis sp. extract.}

291 Caspases are members of the aspartate-specific cysteinyl protease family and are involved in the regulation of apoptosis and inflammation (Kaufmann et al. 1993). Therefore, to corroborate apoptosis induction by Granulocystopsis sp. crude extract on the cancer cell lines, caspase-3 and -7 were measured. Figure 7 shows that the activity of caspases 3 and 7 was increased twice in the tumor cells treated with the Granulocystopsis sp. extract, compared to untreated cancer cells. On the other hand, in Vero (normal) cells, the positive control treated with doxorubicin showed a 
297 higher activation than Vero cells treated with microalgae extract. No differences in caspase

298 activity were observed between cancer cells treated with doxorubicin and those treated with the

299 microalgae extract. Together, these experiments strongly support the conclusion that

300 Granulocystopsis $\mathrm{sp}$. extract has cytotoxic activity induced by apoptotic activation mediated by 301 caspases 3 and/or 7.

302

303 Discussion

In the last three decades, more than 50,000 natural products have been discovered from marine microorganisms, many of them with biomedical applications (Newman \& Cragg 2012; Wiese et synthesize a large number of compounds with different biotechnological applications, including those with anticancer activity. Cyanobacteria, diatoms and chlorophytes are an emerging source for the discovery of new drugs because they are organisms that grow in under-explored extreme environments.

In an attempt to discover new anticancer molecules that may have fewer side effects or reduce resistance to current anticancer drugs, a bioprospecting study of microalgae from $\mathrm{CCB}$, an hyperdiverse oasis in the Chihuahuan desert in Mexico was conducted. A microalgae (strain Chu2) was isolated from the Churince lagoon, and its microscopic morphology coincided with a member of the Oocystaceae family. The molecular identification of the microalgae was carried out using the $r b c L$ gene (which encodes RuBisCO, a fundamental enzyme in the process of photosynthesis), according to the recommendation of the Consortium Barcode Of Life (CBOL) 
320 for the identification of photosynthetic organisms (Group 2009). The DNA sequence was

321 analyzed using BLAST, showing 100\% coverage and percent identity with the $r b c L$ gene

322 previously reported for Granulocystopsis coronata. This information was confirmed by a

323 phylogenetic analysis with other members of the Oocystaceae family. Granulocystopsis is a

324 genus of freshwater microalgae from the Oocystaceae family with 6 names of species

325 taxonomically accepted: G. calyptrata, G. coronata, G. decorata, G. elegans, G. reticulata and

326 G. subcoronata (John \& Tsarenko 2011). However, research papers about this genus are limited

327 to its taxonomy and there are no reports about its biotechnological potential. Although the most

328 abundant photosynthetic aquatic microorganisms reported in CCB are cyanobacteria and diatoms

329 (Pajares et al. 2012; Winsborough et al. 2009), the Churince lagoon used to have several green

330 microalgae, an unexplored group of organisms which, like the Chu2 strain (identified as

331 Granulocystopsis sp.), are adapted to live in oligotrophic conditions, possibly by modifying their

332 metabolism and generating molecules with possible cytotoxic activity against fast-growing

333 eukaryotic organisms in order to avoid competition and obtain phosphorous and nitrogen from

334 the lysed cells in their surroundings. This selective cytotoxicity may explain why they target the

335 fast-growing cancer cells in skin melanoma, colorectal, breast, and prostate cancer without

336 damaging normal cells.

337 Interestingly, in the cell lines evaluated, the $\mathrm{IC}_{50}$ value obtained was from $13.74 \mu \mathrm{g} / \mathrm{mL}$ to 17.44

$338 \mu \mathrm{g} / \mathrm{mL}$, whereas normal cells treated with the microalgae extract showed an $\mathrm{IC}_{50}$ value of 57.02

$339 \mu \mathrm{g} / \mathrm{mL}$ (three times higher than cancer cells). This result revealed that Granulocystopsis sp.

340 extracts have cytotoxic activity which might be helpful in preventing the cancer's progress,

341 especially when it is compared against the activity of other extracts of isolated microalgae from

342 Mexico, such as, Chlorella sorokiniana $\left(\mathrm{IC}_{50} 460 \mu \mathrm{g} / \mathrm{mL}\right)$ and Scenedesmus sp. ( $\mathrm{IC}_{50} 362$ 
$343 \mu \mathrm{g} / \mathrm{mL}$ ) against lymphoma cells (Reyna-Martinez et al. 2018), or other microalgal extracts from

344 Alexandrium minutum $\left(\mathrm{IC}_{50}>50 \mu \mathrm{g} / \mathrm{mL}\right.$ ) against melanoma cells (Lauritano et al. 2016),

345 Haematococcus pluvialis $\left(\mathrm{IC}_{50} 27-72 \mu \mathrm{g} / \mathrm{mL}\right)$ against colon, breast and hepatocellular carcinome

346 (El-Baz et al. 2018), Dunaliella salina $\left(\mathrm{IC}_{50}>400 \mu \mathrm{g} / \mathrm{mL}\right)$ against neuroblastoma cells (Atasever-

347 Arslan et al. 2015), Scenedesmus obliquus ( $\left.\mathrm{IC}_{50} 24-93 \mu \mathrm{g} / \mathrm{mL}\right)$ against colon, hepatocelullar and

348 breast cancer cells (Marrez et al. 2019) and Chloromonas reticulata $\left(\mathrm{IC}_{50}>50 \mu \mathrm{g} / \mathrm{mL}\right)(\mathrm{Suh}$ et al.

349 2019) and Micractinium sp. ( $\mathrm{IC}_{50} 100 \mu \mathrm{g} / \mathrm{mL}$ ) against colon cancer cells (Suh et al. 2018).

350 Additionally, it was corroborated that the microalgae extract has a cytotoxic effect at the level of

351 membrane integrity, using the trypan blue vital dye, which is excluded by an intact cell

352 membrane (Strober 2015). When the cancer cell lines were treated for two days in the presence

353 of microalgae extract, the capability to recover the viability decreased significantly, while the

354 healthy cell line recovered 100\% viability 12 hours after removal of the extract. These results

355 suggest that the extract of Granulocystopsis sp. affects the viability of cancer cells in a time-

356 dependent manner and probably could have tumor-specific activity with minor side effects for

357 normal cells.

358 The ineffectiveness of currently available treatments is mainly due to the invasive and metastatic

359 properties of malignant cancer cells (Lee et al. 2011). Proliferation and cell adhesion are crucial

360 steps that play a significant role in cancer progression and metastasis. The metastatic spread is

361 determined by the cell-cell interactions of cancer cells with endothelium, due to their ability to

362 adhere strongly before they can colonize and establish a secondary tumor in a new place

363 (Chambers et al. 2002). Data obtained from the clonogenic assay, the adhesion and cell

364 morphology tests, showed that extract of Granulocystopsis sp. reduced the ability of cancer cells

365 to form colonies and decreased the attachment ability compared to untreated cells. These results 
366 suggest a potential antimetastatic activity of Granulocystopsis sp. extract, which could be

367 evaluated through migration and cell invasion assays and elucidate possible action mechanisms

368 where some cytoskeleton components were involved. Apoptosis is characterized by a number of

369 characteristic morphological changes in the structure of the cell, together with a number of

370 enzyme-dependent biochemical processes. The result is the clearance of cells from the body,

371 with minimal damage to surrounding tissues and it is the mechanism facilitating the action of

372 many chemotherapeutic drugs. Failure of apoptosis and the resultant accumulation of damaged

373 cells in the body can lead to malignant transformation and result in various forms of cancer

374 (D'Arcy 2019). One technique used to visualize the early and late stages of apoptosis is AO / EB

375 fluorescent staining (Ribble et al. 2005). Our results showed that the microalgae extract activated

376 the apoptosis mechanism in tumor lines. Interestingly, the microalgae extract induced the same

377 level of cells in early and late apoptosis with respect to the anti-cancer compound doxorubicin,

378 suggesting that the extract might contain a more potent compound or a mixture of compounds

379 working in synergy, and therefore, further analyses are required for chromatographic separation

380 and identification of active compounds by NMR, mass spectrometry, etc.

382 The initiation of apoptosis is dependent on the activation of a series of cysteine-aspartic

383 proteases known as caspases (Shi 2002). Caspases can be divided into caspase-8 and -9 (initiator

384 caspases) and caspase-3 and -7 (executioner caspases). Both initiator caspases can activate the

385 caspase-3 or -7 , which are mainly responsible for the final stages of apoptosis, which consist of

386 chromatin segregation, nuclear condensation, and finally DNA fragmentation (Pojarova et al.

387 2007; Yang et al. 2006). Our results showed that apoptosis occurred in melanoma, prostate,

388 colorectal and breast cancer cells treated with microalgal extract, activating caspase-3 and -7, 
389 which were increased manifold over the basal level of untreated cells. Again, the level of

390 activation of caspases was similar among the cancer cells treated with the extract and the

391 compound doxorubicin, which strengthens our proposal for the extract of Granulocystopsis sp. as

392 a good candidate as an anti-cancer drug, which can promote apoptosis in cancer cells via the

393 mitochondrial-dependent intrinsic pathways. The intrinsic pathway can be triggered by

394 irradiation, oxidative stress, hypoxia or cytotoxic drugs (Jan \& Chaudhry 2019). To discover

395 signal transduction involved in triggering apoptosis mediated extract Granulocystopsis sp.,

396 detection of intracellular reactive oxygen species (ROS) level, analysis of mitochondrial

397 membrane potential and Western blotting analysis are required to establish the mechanisms of

398 action of the extract and the participation of Bax/Bak (pro-apoptotic protein inserted into

399 mitochondrial membrane), Bcl-2 (inhibits production of cytochrome c), Cytochrome c (released

400 into the cytosol), Caspase-9 (induced by cytochrome c), and other pro-apoptotic proteins from

401 the intrinsic pathway like Smac/Diablo, Apaf-1, among others, leading to the activation of

402 caspase-3. Because there are studies that confirm the participation of polyphenols in the

403 induction of apoptosis in tumor cells (Sharif et al. 2010; Walter et al. 2010), more experiments

404 are required to demonstrate if any phenolic compound present in the Granulocystopsis sp. extract

405 could be initiating the transduction signal from the intrinsic pathway.

406 Based on our results, the microalgal extract may be useful for the future development of anti-

407 metastatic therapeutic agents. The current research aimed at the description of the molecular

408 mechanisms of the anticancer properties of the microalgae extract, as well as the elucidation of

409 the bioactive molecule, is being performed.

410

411 


\section{Conclusions}

413 The current study represents the first report showing the anticancer activity derived from

414 Granulocystopsis sp., an isolated microalgae from the Chihuahuan desert. The microalgae

415 methanolic extract inhibited cell proliferation, showed time-dependent cytotoxic activity,

416 modified morphology, decreased cell adhesion and induced apoptosis by activating caspases 3/7

417 in breast, colon, prostate and skin melanoma cancer cell lines, but showed less pronounced

418 effects on normal cells.

\section{Acknowledgments}

421 We would like to thank our colleagues Dr. Mariana Elizondo Zertuche and Álvaro Colín Oviedo

422 for their support with fluorescence microscope (CONACYT-INFRA 2015-251142), at

423 Departamento de Microbiología, Facultad de Medicina, UANL. We thank Alberto Ramos-Silva

424 for technical assistance, Jorge Alberto Balderas-Soriano for the preliminary results and Abigail

425 Mata-Aguilar for keeping the CCB microalgae culture collection. We also want to thank "Centro

426 de Bachillerato Tecnológico Agropecuario \#22" for providing facilities during the sampling

427 period and we thank SEMARNAT for access to the CCB Natural Protected Area

428 and permission to sample there.

\section{References}

430

431

432

433

434

435

436

437

438
Atasever-Arslan B, Yilancioglu K, Bekaroglu MG, Taskin E, Altinoz E, and Cetiner S. 2015. Cytotoxic effect of extract from Dunaliella salina against SH-SY5Y neuroblastoma cells. Gen Physiol Biophys 34:201-207. 10.4149/gpb_2014034

Chambers AF, Groom AC, and MacDonald IC. 2002. Dissemination and growth of cancer cells in metastatic sites. Nat Rev Cancer 2:563-572. 10.1038/nrc865

Cohen JJ. 1993. Apoptosis. Immunol Today 14:126-130. 10.1016/0167-5699(93)90214-6

Collins TJ. 2007. ImageJ for microscopy. Biotechniques 43:25-30. 10.2144/000112517

D'Arcy MS. 2019. Cell death: a review of the major forms of apoptosis, necrosis and autophagy. Cell Biol Int 43:582-592. 10.1002/cbin.11137 
439

440

441

442

443

444

445

446

447

448

449

450

451

452

453

454

455

456

457

458

459

460

461

462

463

464

465

466

467

468

469

470

471

472

473

474

475

476

477

478

479

480

481

482

483

484

485

El-Baz FK, Hussein RA, Mahmoud K, and Abdo SM. 2018. Cytotoxic activity of carotenoid rich fractions from Haematococcus pluvialis and Dunaliella salina microalgae and the identification of the phytoconstituents using LC-DAD/ESI-MS. Phytother Res 32:298-304. 10.1002/ptr.5976

Elser JJ, Schampel JH, Garcia-Pichel F, Wade BD, Souza V, Eguiarte LE, Escalante AE, and Farmer J. 2005. Effects of phosphorus enrichment and grazing snails on modern stromatolitic microbial communities. FRESH WATER BIOLOGY 50:1808-1825. doi:10.1111/j.1365-2427.2005.01451.x

Eskandani M, Hamishehkar H, and Ezzati Nazhad Dolatabadi J. 2014. Cytotoxicity and DNA damage properties of tert-butylhydroquinone (TBHQ) food additive. Food Chem 153:315-320. 10.1016/j.foodchem.2013.12.087

Felsenstein J. 1985. Confidence Limits on Phylogenies: An Approach Using the Bootstrap. Evolution 39:783-791. 10.1111/j.1558-5646.1985.tb00420.x

Group CPW. 2009. A DNA barcode for land plants. Proc Natl Acad Sci U S A 106:12794-12797. 10.1073/pnas.0905845106

Higgins DG. 1994. CLUSTAL V: multiple alignment of DNA and protein sequences. Methods Mol Biol 25:307-318. 10.1385/0-89603-276-0:307

Irigoien X, Huisman J, and Harris RP. 2004. Global biodiversity patterns of marine phytoplankton and zooplankton. Nature 429:863-867. 10.1038/nature02593

Jan R, and Chaudhry GE. 2019. Understanding Apoptosis and Apoptotic Pathways Targeted Cancer Therapeutics. Adv Pharm Bull 9:205-218. 10.15171/apb.2019.024

John DM, and Tsarenko PM. 2011. Phylum Chlorophyta. Order Chlorococcales. In: John DM, Whitton BA, and Brook AJ, eds. The freshwater algal flora of the british isles. Second edition ed. Cambridge: Cambridge University Press, 484-485.

Kaufmann SH, Desnoyers S, Ottaviano Y, Davidson NE, and Poirier GG. 1993. Specific proteolytic cleavage of poly(ADP-ribose) polymerase: an early marker of chemotherapy-induced apoptosis. Cancer Res 53:3976-3985.

Kumar S, Stecher G, and Tamura K. 2016. MEGA7: Molecular Evolutionary Genetics Analysis Version 7.0 for Bigger Datasets. Mol Biol Evol 33:1870-1874. 10.1093/molbev/msw054

Lauritano C, Andersen JH, Hansen E, Albrigtsen M, Escalera L, Esposito F, Helland K, Hanssen $\varnothing$, Romano G, and lanora A. 2016. Bioactivity screening of microalgae for antioxidant, anti-inflammatory, anticancer, anti-diabetes, and antibacterial activities. Frontiers in Marine Science 3:68. $\mathrm{DOI}=10.3389 /$ fmars.2016.00068

Lee SH, Jaganath IB, Wang SM, and Sekaran SD. 2011. Antimetastatic effects of Phyllanthus on human lung (A549) and breast (MCF-7) cancer cell lines. PLoS One 6:e20994. 10.1371/journal.pone.0020994

Lopez-Lozano NE, Eguiarte LE, Bonilla-Rosso G, Garcia-Oliva F, Martinez-Piedragil C, Rooks C, and Souza V. 2012. Bacterial communities and the nitrogen cycle in the gypsum soils of Cuatro Cienegas Basin, coahuila: a Mars analogue. Astrobiology 12:699-709. 10.1089/ast.2012.0840

Marrez DA, Naguib MM, Sultan YY, and Higazy AM. 2019. Antimicrobial and anticancer activities of Scenedesmus obliquus metabolites. Heliyon 5:e01404. 10.1016/j.heliyon.2019.e01404

Martinotti S, Ranzato E, and Burlando B. 2018. (-)- Epigallocatechin-3-gallate induces GRP78 accumulation in the ER and shifts mesothelioma constitutive UPR into proapoptotic ER stress. $J$ Cell Physiol 233:7082-7090. 10.1002/jcp.26631

Milne I, Lindner D, Bayer M, Husmeier D, McGuire G, Marshall DF, and Wright F. 2009. TOPALi v2: a rich graphical interface for evolutionary analyses of multiple alignments on HPC clusters and multicore desktops. Bioinformatics 25:126-127. 10.1093/bioinformatics/btn575

Minckley WL, and Cole GA. 1968. Preliminary Limnologic Information on Waters of the Cuatro Cienegas Basin, Coahuila, Mexico. The Southwestern Naturalist 13:421-431. DOI: 10.2307/3668909

PeerJ reviewing PDF | (2019:11:43452:1:1:NEW 16 Jan 2020) 
486

487

488

489

490

491

492

493

494

495

496

497

498

499

500

501

502

503

504

505

506

507

508

509

510

511

512

513

514

515

516

517

518

519

520

521

522

523

524

525

526

527

528

529

530

531

532

533
Newman DJ, and Cragg GM. 2012. Natural products as sources of new drugs over the 30 years from 1981 to 2010. J Nat Prod 75:311-335. 10.1021/np200906s

Pajares S, Bonilla-Rosso G, Travisano M, Eguiarte LE, and Souza V. 2012. Mesocosms of aquatic bacterial communities from the Cuatro Cienegas Basin (Mexico): a tool to test bacterial community response to environmental stress. Microb Ecol 64:346-358. 10.1007/s00248-012-0045-7

Pojarova M, Kaufmann D, Gastpar R, Nishino T, Reszka P, Bednarski PJ, and von Angerer E. 2007. [(2Phenylindol-3-yl)methylene]propanedinitriles inhibit the growth of breast cancer cells by cell cycle arrest in G(2)/M phase and apoptosis. Bioorg Med Chem 15:7368-7379. 10.1016/j.bmc.2007.07.046

Rafehi H, Orlowski C, Georgiadis GT, Ververis K, El-Osta A, and Karagiannis TC. 2011. Clonogenic assay: adherent cells. J Vis Exp. 10.3791/2573

Reyna-Martinez R, Gomez-Flores R, Lopez-Chuken U, Quintanilla-Licea R, Caballero-Hernandez D, Rodriguez-Padilla C, Beltran-Rocha JC, and Tamez-Guerra P. 2018. Antitumor activity of Chlorella sorokiniana and Scenedesmus sp. microalgae native of Nuevo Leon State, Mexico. PeerJ 6:e4358. 10.7717/peerj.4358

Ribble D, Goldstein NB, Norris DA, and Shellman YG. 2005. A simple technique for quantifying apoptosis in 96-well plates. BMC Biotechnol 5:12. 10.1186/1472-6750-5-12

Sharif T, Auger C, Alhosin M, Ebel C, Achour M, Etienne-Selloum N, Fuhrmann G, Bronner C, and SchiniKerth VB. 2010. Red wine polyphenols cause growth inhibition and apoptosis in acute lymphoblastic leukaemia cells by inducing a redox-sensitive up-regulation of p73 and downregulation of UHRF1. Eur J Cancer 46:983-994. 10.1016/j.ejca.2009.12.029

Shi Y. 2002. Mechanisms of caspase activation and inhibition during apoptosis. Mol Cell 9:459-470. 10.1016/s1097-2765(02)00482-3

Singh RK, Tiwari SP, Rai AK, and Mohapatra TM. 2011. Cyanobacteria: an emerging source for drug discovery. J Antibiot (Tokyo) 64:401-412. 10.1038/ja.2011.21

Skehan P, Storeng R, Scudiero D, Monks A, McMahon J, Vistica D, Warren JT, Bokesch H, Kenney S, and Boyd MR. 1990. New colorimetric cytotoxicity assay for anticancer-drug screening. J Nat/ Cancer Inst 82:1107-1112. 10.1093/jnci/82.13.1107

Souza V, Eguiarte LE, Siefert J, and Elser JJ. 2008. Microbial endemism: does phosphorus limitation enhance speciation? Nat Rev Microbiol 6:559-564. 10.1038/nrmicro1917

Souza V, Espinosa-Asuar L, Escalante AE, Eguiarte LE, Farmer J, Forney L, Lloret L, Rodriguez-Martinez JM, Soberon X, Dirzo R, and Elser JJ. 2006. An endangered oasis of aquatic microbial biodiversity in the Chihuahuan desert. Proc Natl Acad Sci U S A 103:6565-6570. 10.1073/pnas.0601434103

Souza V, Moreno-Letelier A, Travisano M, Alcaraz LD, Olmedo G, and Eguiarte LE. 2018. The lost world of Cuatro Cienegas Basin, a relictual bacterial niche in a desert oasis. Elife 7. 10.7554/eLife.38278

Souza V, Siefert JL, Escalante AE, Elser JJ, and Eguiarte LE. 2012. The Cuatro Cienegas Basin in Coahuila, Mexico: an astrobiological Precambrian Park. Astrobiology 12:641-647. 10.1089/ast.2011.0675

Stenclova L, Fucikova K, Kastovsky J, and Pazoutova M. 2017. Molecular and morphological delimitation and generic classification of the family Oocystaceae (Trebouxiophyceae, Chlorophyta). J Phycol 53:1263-1282. 10.1111/jpy.12581

Strober W. 2015. Trypan Blue Exclusion Test of Cell Viability. Curr Protoc Immunol 111:A3 B 1-A3 B 3. 10.1002/0471142735.ima03bs111

Suh SS, Hong JM, Kim EJ, Jung SW, Chae H, Kim JE, Kim JH, Kim IC, and Kim S. 2019. Antarctic freshwater microalga, Chloromonas reticulata, suppresses inflammation and carcinogenesis. Int J Med Sci 16:189-197. 10.7150/ijms.30647

Suh SS, Hong JM, Kim EJ, Jung SW, Kim SM, Kim JE, Kim IC, and Kim S. 2018. Anti-inflammation and AntiCancer Activity of Ethanol Extract of Antarctic Freshwater Microalga, Micractinium sp. Int J Med Sci 15:929-936. 10.7150/ijms.26410

Peer] reviewing PDF | (2019:11:43452:1:1:NEW 16 Jan 2020) 
534

van Meerloo J, Kaspers GJ, and Cloos J. 2011. Cell sensitivity assays: the MTT assay. Methods Mol Biol 731:237-245. 10.1007/978-1-61779-080-5_20

Varshney A, and Singh V. 2013. Effects algal compounds on cancer cell line. Journal of Experimental Biology and Agricultural Sciences 1:337-352.

Walter A, Etienne-Selloum N, Brasse D, Khallouf H, Bronner C, Rio MC, Beretz A, and Schini-Kerth VB. 2010. Intake of grape-derived polyphenols reduces $C 26$ tumor growth by inhibiting angiogenesis and inducing apoptosis. FASEB J 24:3360-3369. 10.1096/fj.09-149419

Wiese J, Thiel V, Nagel K, Staufenberger T, and Imhoff JF. 2009. Diversity of antibiotic-active bacteria associated with the brown alga Laminaria saccharina from the Baltic Sea. Mar Biotechnol (NY) 11:287-300. 10.1007/s10126-008-9143-4

Winsborough BM, Theriot E, and Czarnecki DB. 2009. Diatoms on a continental "island": Lazarus species, marine disjuncts and other endemic diatoms of the Cuatro Ciénegas basin, Coahuila, México. Nova Hedwigia, Beiheft 135:257-274.

Xia SH, Wang J, and Kang JX. 2005. Decreased n-6/n-3 fatty acid ratio reduces the invasive potential of human lung cancer cells by downregulation of cell adhesion/invasion-related genes. Carcinogenesis 26:779-784. 10.1093/carcin/bgi019

Yang HL, Chen CS, Chang WH, Lu FJ, Lai YC, Chen CC, Hseu TH, Kuo CT, and Hseu YC. 2006. Growth inhibition and induction of apoptosis in MCF-7 breast cancer cells by Antrodia camphorata. Cancer Lett 231:215-227. 10.1016/j.canlet.2005.02.004

\section{Figure Legends}

Figure 1. Microscopy of Granulocystopsis sp. Cells ellipsoidal retained in enlarged parent wall.

A-C Bright field. D-F Phase contrast. A and D colonia with 2 cells. B and D colonia with 4 cells. C and F colonia with 8 cells. Scale bar $10 \mu \mathrm{m}$.

Figure 2. Phylogenetic tree of Oocystaceae family based on the $r b c L$ gene. Maximum

likelihood (ML) method, constructed by the Generalised time-reversible GTR $+\mathrm{G}$ parameter as an evolutionary model with 1,000 bootstrap replicates. Bootstrap values for ML in the range from 0.7 to 1 were marked with black rhombus.

Figure 3. Changes in cell viability during 48 hours of treatment with microalgae extract and 24 hours of recovery. Human cancer cells were treated at the corresponding $\mathrm{IC}_{50}$ 
565 concentration for each cell line. Cell viability was evaluated by MTT assay. Each data point

566 represents values from three independent experiments $(\mathrm{n}=5)$. Error bar indicates mean $\pm \mathrm{SEM}$.

567

568 Figure 4. Colony forming assay of cancer cells in response to treatment with microalgal

569 extract. Cells of four cancer cell lines were incubated for 10-14 days with microalgal extract at

570 the corresponding IC50 concentration. (A, C, E, G and I) Representative images show the clones

571 formed under the control conditions. (B, D, F, H and J) Representative images show the clones

572 formed under the treatment conditions. (K) The number of clones formed after the treatment was

573 counted and presented as histograms. The results are representative of three independent

574 experiments and the level of significance was determined using Student t-Test with

575 nsrepresenting, $\mathrm{p}>0.05 ; * * * *$ represents, $\mathrm{p}<0.0001$; **represents, $\mathrm{p}<0.01$; and *represents 1 .

576

577 Figure 5. Effects of Chu2 microalgae extract on the morphology and cell attachment.

578 Human cancer cells were treated with $\mathrm{IC}_{50}$ corresponding value for each cell line for $48 \mathrm{~h}$ and

579 then, the cells were trypsinized and plated on a new culture dish without extract. After a period 580 of $0 \mathrm{~h}, 6 \mathrm{~h}, 12 \mathrm{~h}$ and $24 \mathrm{~h}$, the images were captured with a phase-contrast microscope.

581 Representative results from three independent experiments are shown.+Ext, treated cells. -Ext, 582 control (untreated) cells.

Figure 6. AO/EB double stain of human cancer cell lines after a treatment with microalgal extract. (A) Prostate (D) and melanoma skin (C) cells were treated with microalgal extract at the corresponding $\mathrm{IC}_{50}$ concentration. Images represent the control (B and $\mathrm{A}$, untreated cells), treated 
588 positive control ( $\mathrm{F}$ and $\mathrm{E}$ ). Cells were stained with acridine orange and ethidium bromide 589 (AO/EB) after $48 \mathrm{~h}$ of treatment. $(\mathrm{G}$ and $\mathrm{H})$ Error bar indicates mean $\pm \mathrm{SEM}$ of three independent 590 experiments. +Ext and +Dox, cells treated with microalgal extract or doxorubicin, respectively. 591 White arrows indicate live (L), early apoptotic (EA), late apoptotic (LA) or necrotic (N) cells. 592 Different letters represent statistically significant differences determined by one way ANOVA $(\rho$ $593<0.05)$ between bars with the same color by cell line.

595 Figure 7. Caspase-3/7 activty on cancer cell lines treated with Granulocystopsis sp. 596 microalgal extract. Quantitative assessment of caspase activity in prostate, melanoma, 597 colorectal and breast cancer cell lines. Vero is a normal cell line. Cells were treated with 598 Granulocystopsis sp. extract at the corresponding $\mathrm{IC}_{50}$ concentration for each cell line. Error bar 599 indicates the standard error of the mean of Relative Fluorescence Units (RFU) of three 600 independent experiments. Different letter represents statistically significant differences 601 determined by one way ANOVA $(\rho<0.05)$ between bars with different color by cell line. 


\section{Table 1 (on next page)}

Primer sequences used in this study. 
2

3 TABLE 1. Primer sequences used in this study.

\begin{tabular}{lll}
\hline Primer name & Secuence (5'-3') & Product size (pb) \\
\hline RbcL-192-F & GGTACTTGGACAACWGTWTGGAC & 500 \\
RbcL-657-R & GAAACGGTCTCKCCARCGCAT & \\
RbcLZ-F & CAACCAGGTGTTCCASCTGAAG & $1100-1200$ \\
RbcLZ-R & CTAAAGCTGGCATGTGCCATAC & \\
& & \\
\hline
\end{tabular}

4 
Table 2 (on next page)

Strains and plasmid used in this study. 
1 TABLE 2. Strains and plasmid used in this study.

Strain/Plasmid Relevant properties

Source or Reference

names

$\mathrm{F}-\varphi 80$ lacZM15 endA recA $h s d R\left(\mathrm{r}-{ }_{\mathrm{K}} \mathrm{m}-{ }_{\mathrm{K}}\right)$ supE thi Laboratory stock

E.coli DH5a $\quad$ gyrA relA $\Delta($ lacZYA-argF $) \mathrm{U} 169$

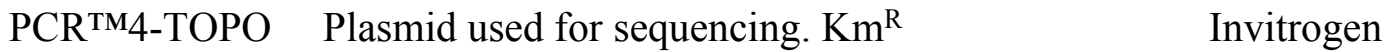

pFT4 PCR ${ }^{\text {TM4-TOPO, Chu2_RbcLZ This study }}$

pFT5 PCR ${ }^{\text {TM4-TOPO, Chu2_rbcL192/657 This study }}$

2

3

4

5 


\section{Table 3 (on next page)}

$\mathrm{IC}_{50}$ values $(\mu \mathrm{g} / \mathrm{ml})$ of Granulocystopsis sp. methanol crude extract on prostate, breast, colorectal, skin melanoma, and lung cancer cell lines.

Human cancer cell lines were treated with different concentrations of Granulocystopsis sp. methanol crude extract in 96-well microculture plates for $48 \mathrm{~h}$. IC $\mathrm{C}_{50}$ values are expressed as mean \pm standard error of mean (S.E.M) of quintuplicate determinations. Different letters represent statistically significant differences determined by one-way ANOVA $(\rho<0.05)$. 
1 TABLE 3. $\mathrm{IC}_{50}$ values $(\mu \mathrm{g} / \mathrm{ml})$ of Granulocystopsis sp. methanol crude extract on prostate,

2 breast, colorectal, skin melanoma, and lung cancer cell lines.

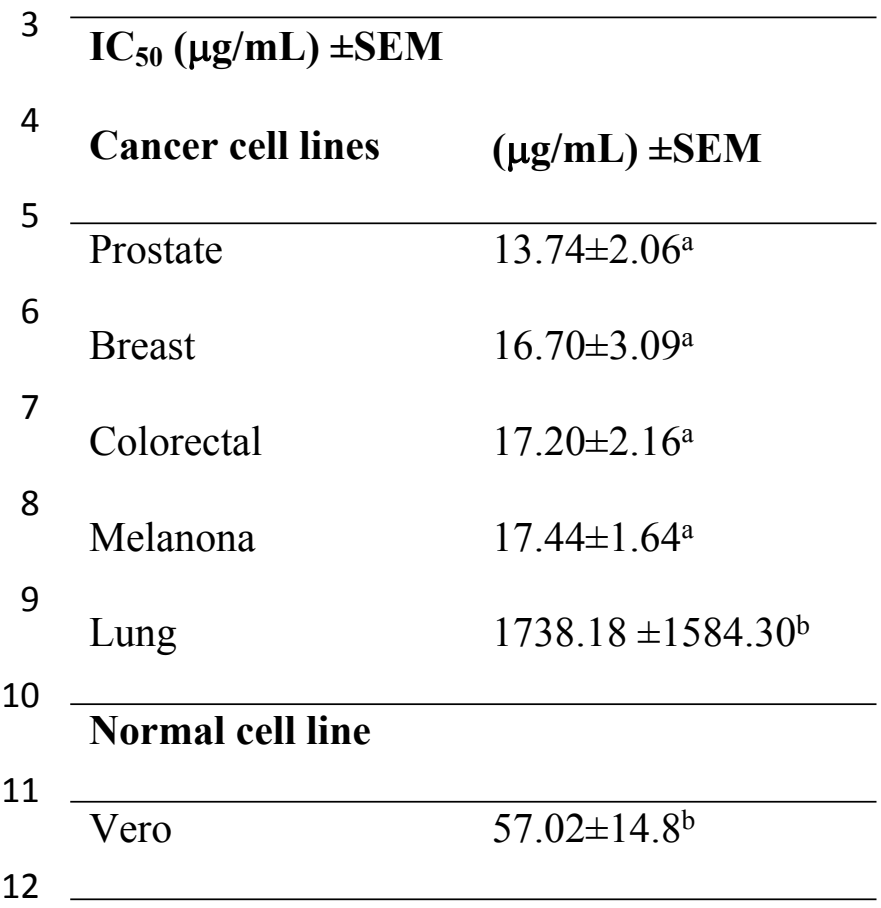

13

14 Human cancer cell lines were treated with different concentrations of Granulocystopsis sp.

15 methanol crude extract in 96 -well microcultured plates for $48 \mathrm{~h}$. $\mathrm{IC}_{50}$ values are expressed as mean

$16 \pm$ standard error of mean (S.E.M) of quintuplicate determinations. Different letters represent

17 statistically significant differences determined by one-way ANOVA $(\rho<0.05)$.

18

19 
Figure 1

Microscopy of Granulocystopsis sp.

Cells ellipsoidal retained in enlarged parent wall. A-C Bright field. D-F Phase contrast. A and D colonia with 2 cells. B and D colonia with 4 cells. C and F colonia with 8 cells. Scale bar 10 $\mu \mathrm{m}$. 


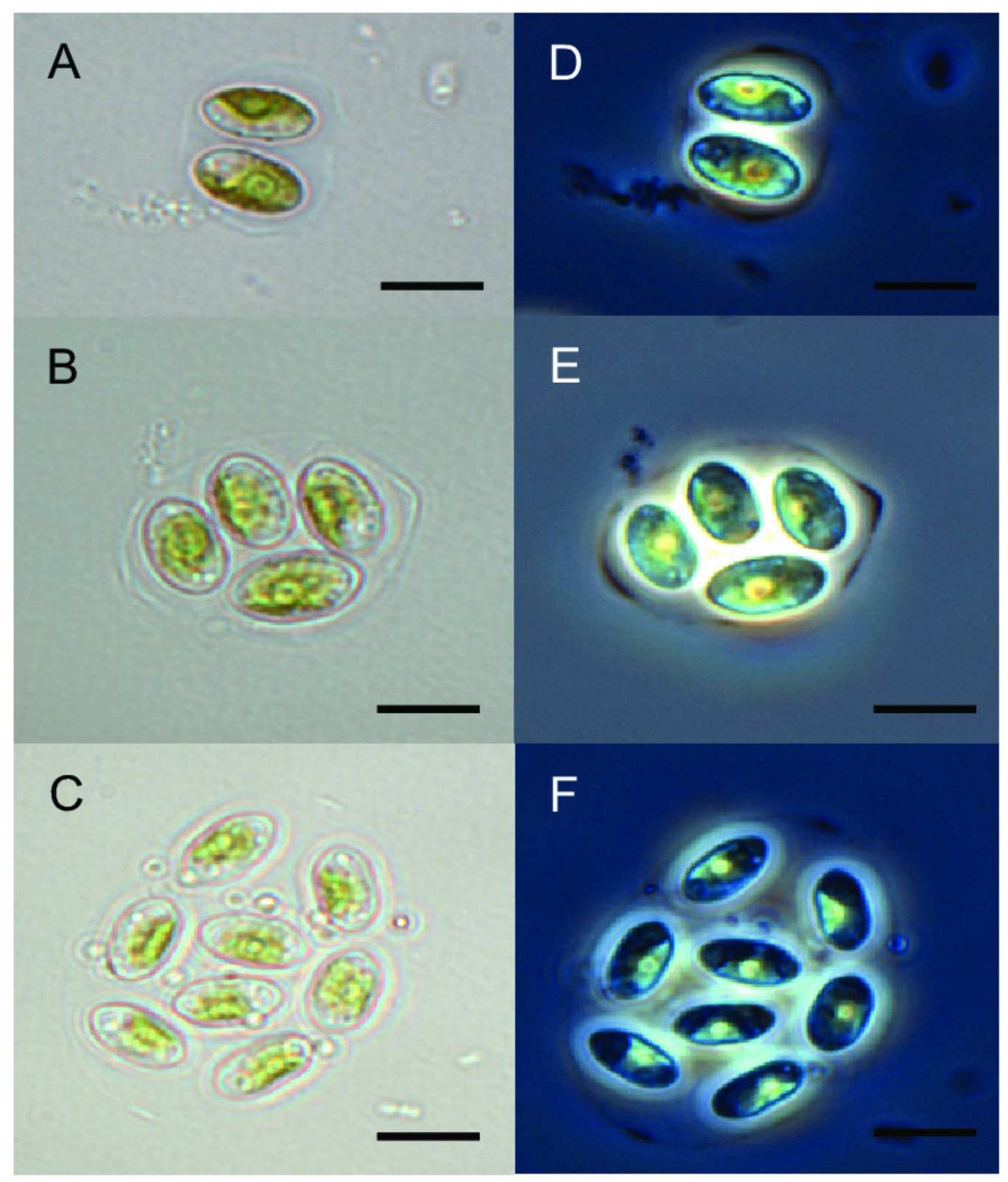


Figure 2

Phylogenetic tree of Oocystaceae family based on the $r b c L$ gene

Maximum likelihood (ML) method, constructed by the Generalised time-reversible $G T R+G$ parameter as an evolutionary model with 1,000 bootstrap replicates. Bootstrap values for $\mathrm{ML}$ in the range from 0.7 to 1 were marked with black rhombus. 


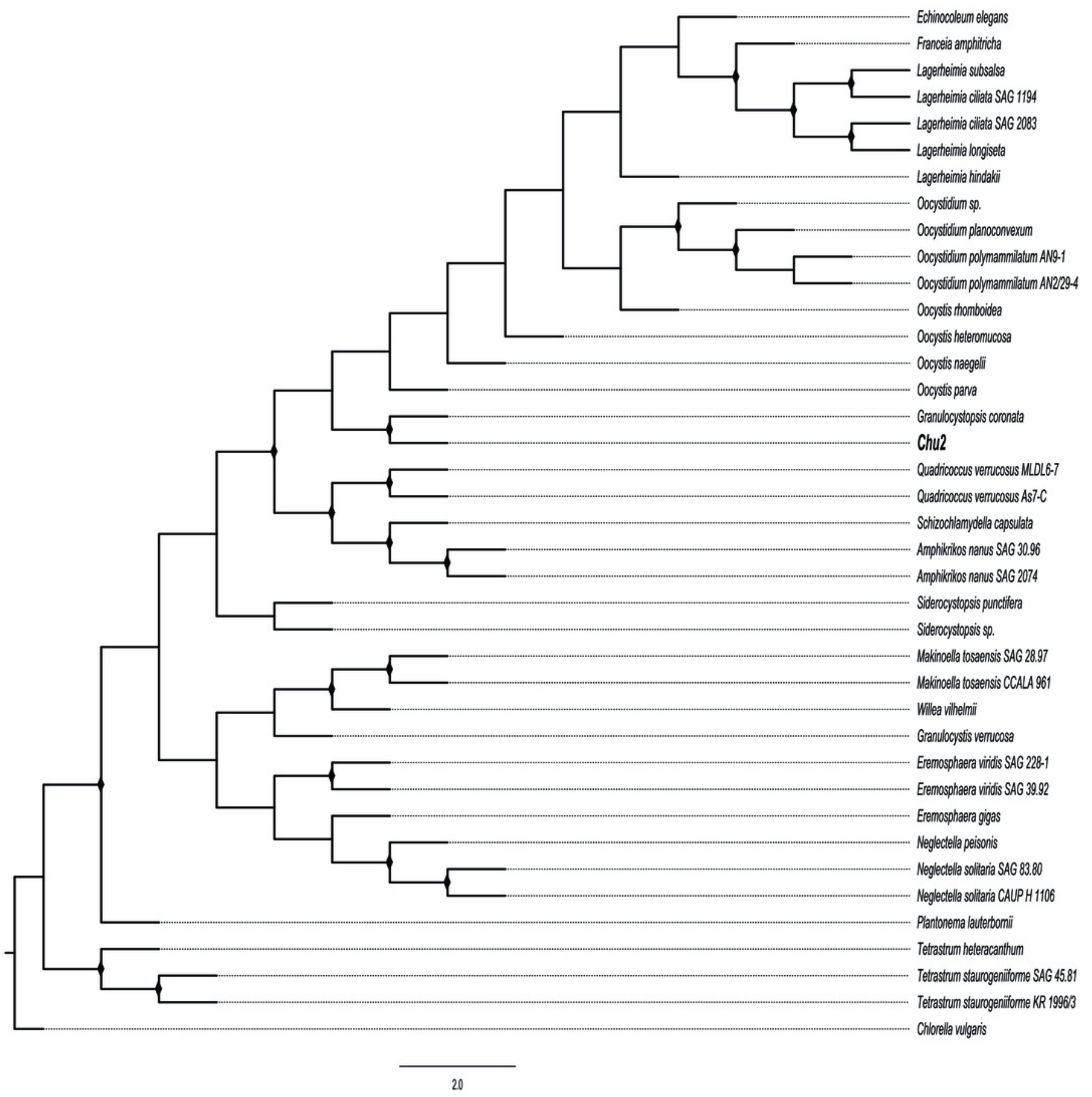


Figure 3

Changes in cell viability during 48 hours of treatment with microalgae extract and 24 hours of recovery.

Human cancer cells were treated at the corresponding $I C_{50}$ concentration for each cell line. Cell viability was evaluated by MTT assay. Each data point represents values from three independent experiments $(n=5)$. Error bar indicates mean \pm SEM.

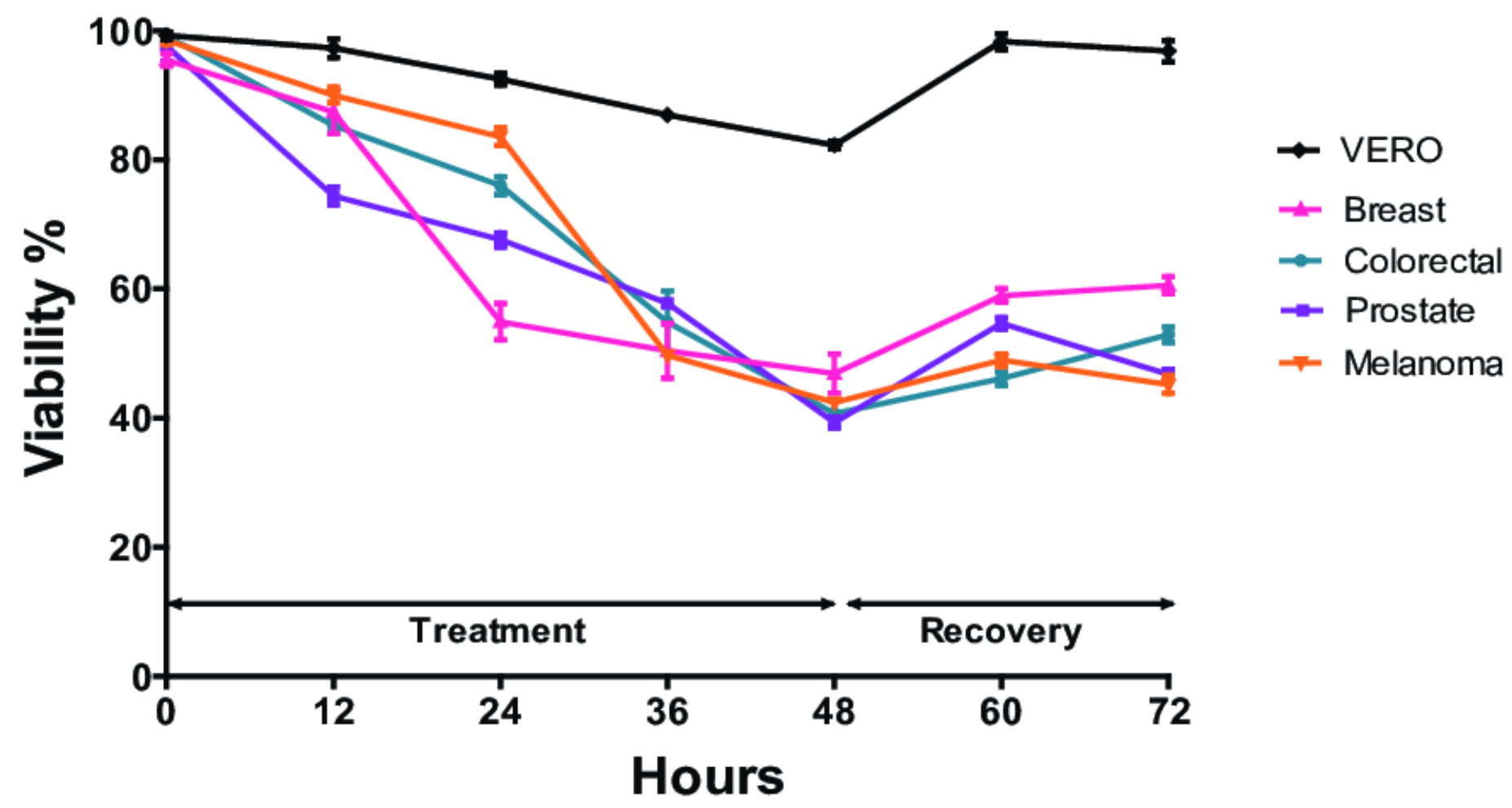




\section{Figure 4}

Colony forming assay of cancer cells in response to treatment with microalgal extract.

Cells of four cancer cell lines were incubated for 10-14 days with microalgal extract at the corresponding $\mathrm{IC}_{50}$ concentration. (A) Representative images show the clones formed under the treatment condition. (B) The number of clones formed after the treatment was counted and presented as histograms. The results are representative of three independent experiments and the level of significance was determined using Student $t$-Test with ${ }^{\text {ns }}$ representing, $p>0.05 ; * * * *$ represents, $p<0.0001 ;{ }^{* *}$ represents, $p<0.01$; and *represents 1 .

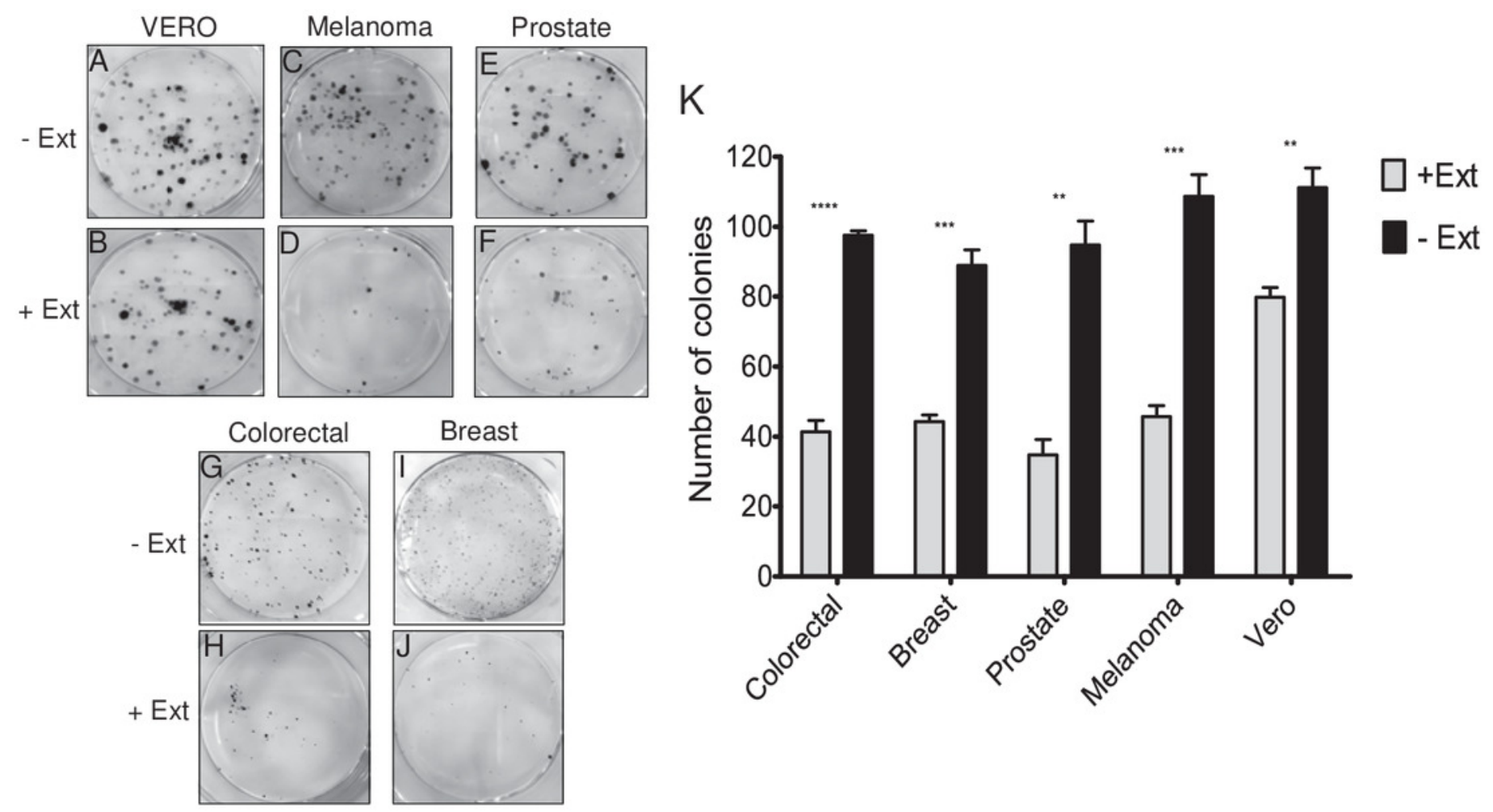




\section{Figure 5}

Effects of Chu2 microalgae extract on the morphology and cell attachment.

Human cancer cells were treated with $\mathrm{IC}_{50}$ corresponding value for each cell line for $48 \mathrm{~h}$ and then, the cells were trypsinized and plated on a new culture dish without extract. After a period of $0 \mathrm{~h}, 6 \mathrm{~h}, 12 \mathrm{~h}$ and $24 \mathrm{~h}$, the images were captured with a phase contrast microscope. Representative results from three independent experiments are shown.+Ext, treated cells. -Ext, control (untreated) cells. 

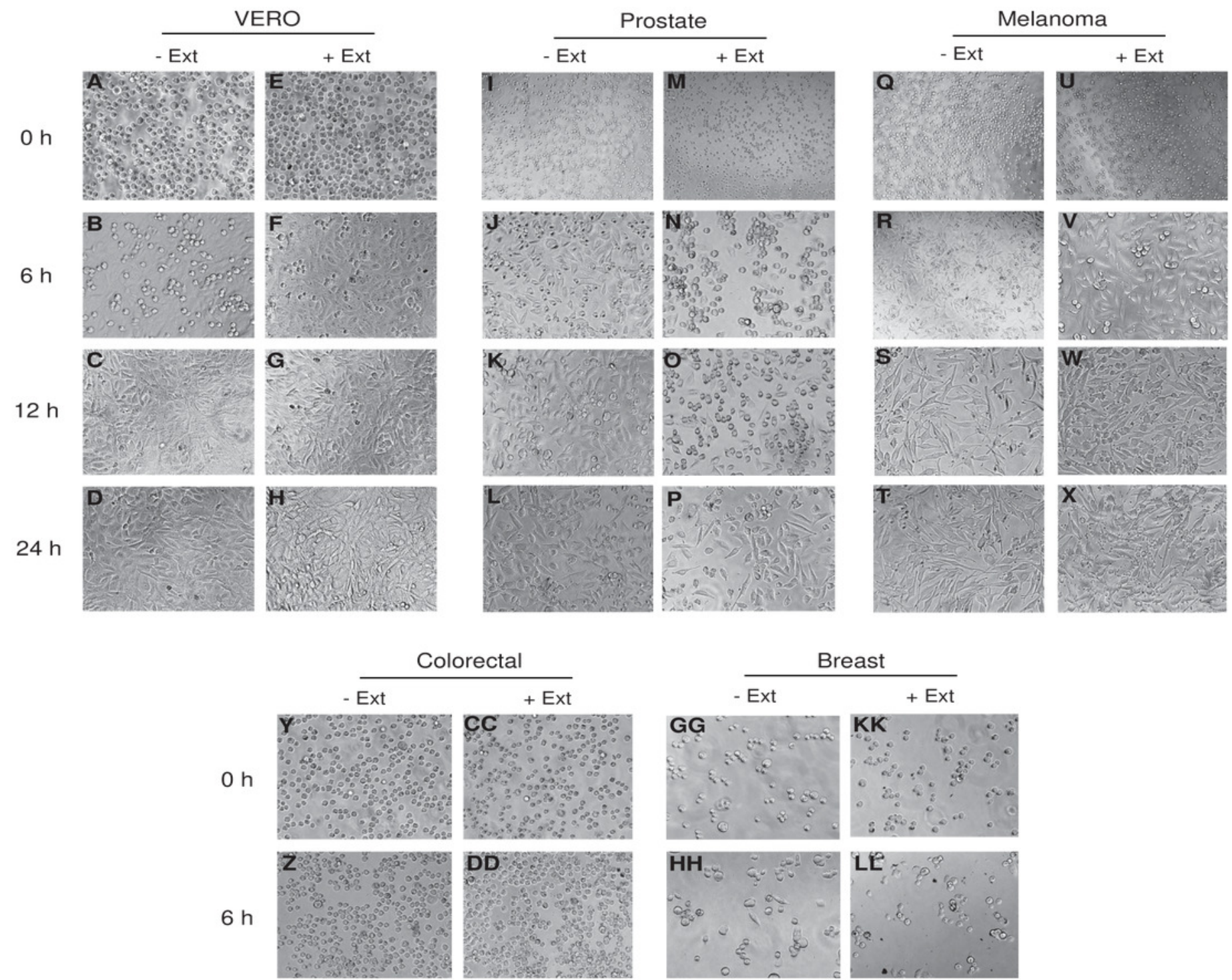

Colorectal
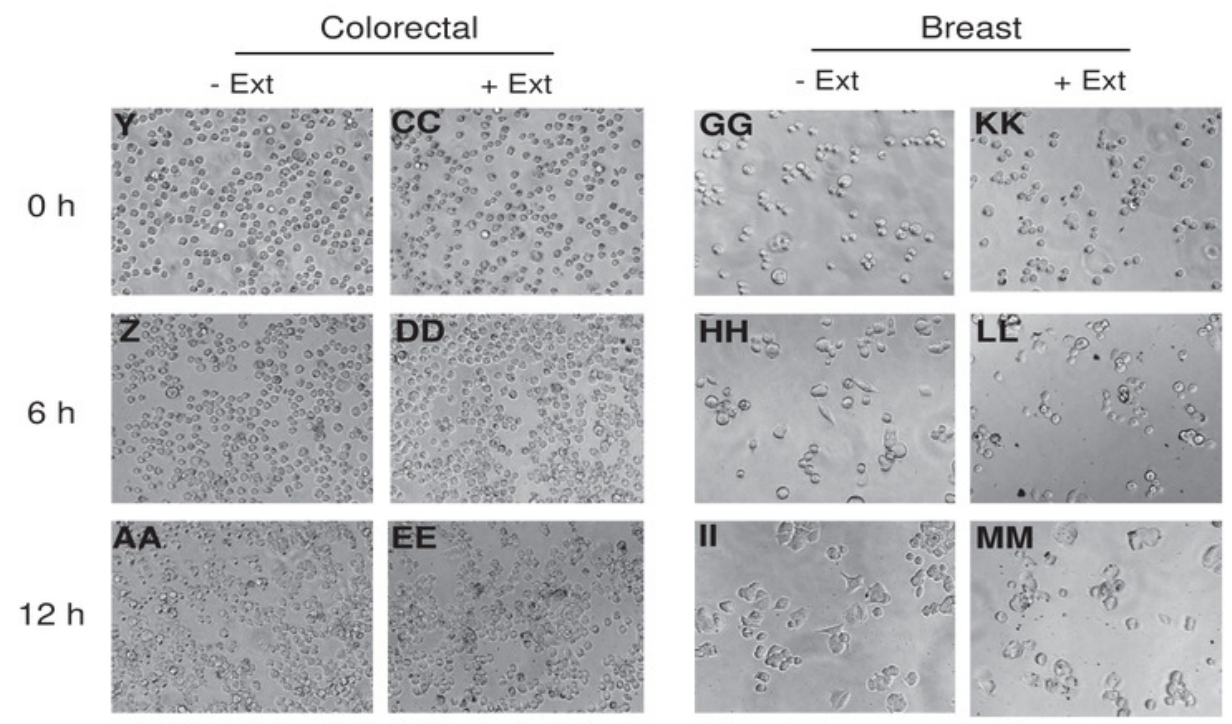

$24 \mathrm{~h}$
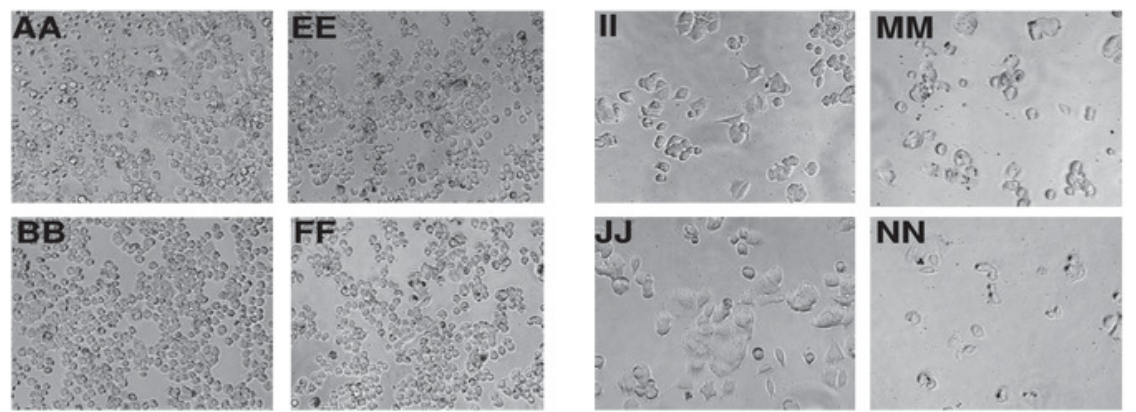


\section{Figure 6}

AO/EB double stain of human cancer cell lines after a treatment with microalgal extract.

(A) Prostate and melanoma skin cells were treated with microalgal extract at the corresponding $\mathrm{IC}_{50}$ concentration. Images represent the control (untreated cells), treated cells with microalgae extract and, cell treated with doxorubicin $(10 \mu \mathrm{g} / \mathrm{mL})$ as positive control. Cells were stained with acridine orange and ethidium bromide (AO/EB) after $48 \mathrm{~h}$ of treatment. (B) Error bar indicates mean \pm SEM of three independent experiments. +Ext and +Dox, cells treated with microalgal extract or doxorubicin, respectively. White arrows indicate live (L), early apoptotic (EA), late apoptotic (LA) or necrotic (N) cells. Different letters represents statistically significant differences determined by one way ANOVA $(\rho<0.05)$ between bars with same color by cell line. 

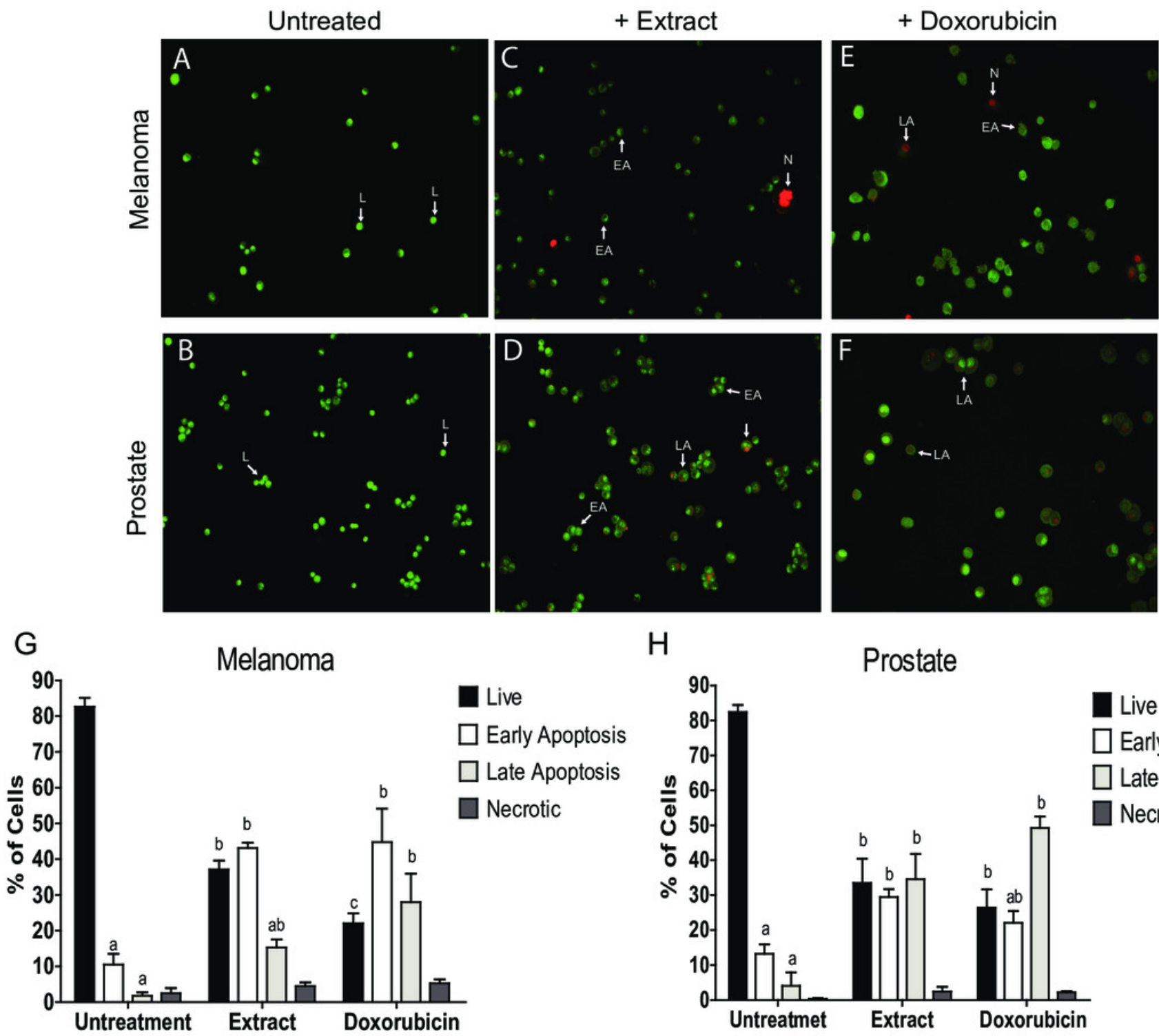

$\mathrm{H}$

Prostate

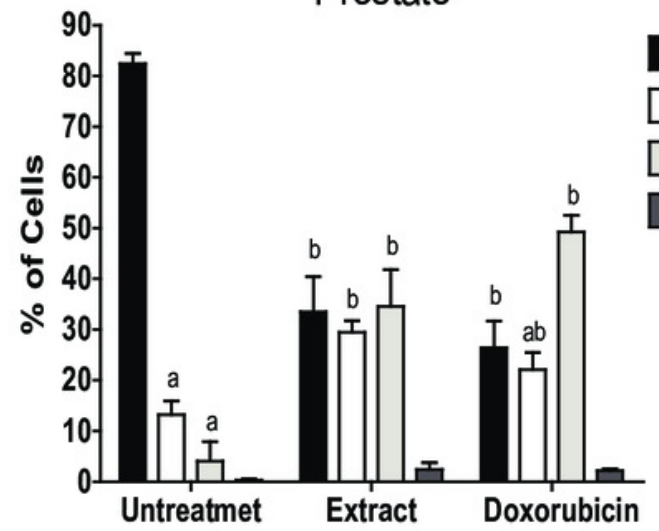

Live

$\square$ Early Apoptosis

$\square$ Late Apoptosis

Necrotic

Necrotic 


\section{Figure 7}

Caspase-3/7 activty on cancer cell lines treated with Granulocystopsis sp. microalgal extract.

Quantitative assessment of caspase activity in prostate, melanoma, colorectal and breast cancer cell lines. Vero is a normal cell line. Cells were treated with Granulocystopsis sp. extract at the corresponding $I C_{50}$ concentration for each cell line. Error bar indicates the standard error of the mean of Relative Fluorescence Units (RFU) of three independent experiments. Different letter represents statistically significant differences determined by one way ANOVA $(\rho<0.05)$ between bars with different color by cell line.

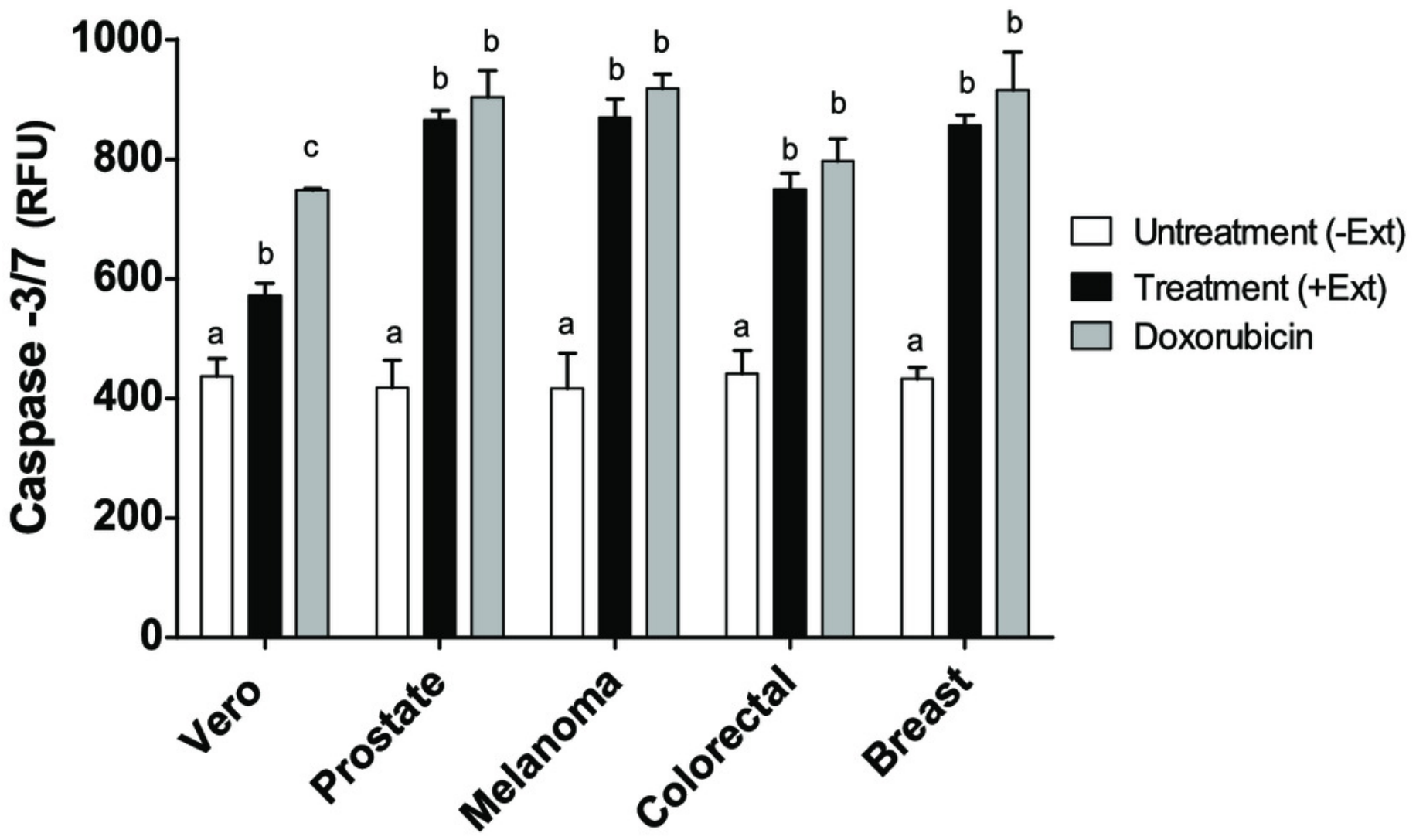

